\title{
Diminished Lives and Malpractice: Courts Stalled in Transition
}

\author{
by Barry R. Furrow, J.D.
}

Medicine is still largely a pre-Darwin, pre-Newton enterprise. . . . We do not yet understand the underlying mechanisms of the major illnesses which plague humanity, and therefore much of what is done in the treatment of illness must still be empirical, trial and error therapy. We are compelled by our limitations to resort to shoring things up, applying halfway technology, trying to fix things after the fact."

$\mathrm{T}$

he judicial debate continues to rage over the right of a child born suffering from genetic impairments to recover on his own behalf against a physician or laboratory which failed to give his parents correct information about the defect. These "wrongful life" suits are brought by parents on behalf of their child, who in most cases is born suffering from mental or physical defects which could have been detected by genetic screening. In contrast, "wrongful birth" suits are actions brought by parents of a child born as the result of a defendant's negligence, seeking damages for either the costs incident to the unwanted pregnancy and birth of a normal child, or the costs related to the unexpected birth and care of an impaired child. The two actions are distinguished by who may bring them - the parents or the child. ${ }^{2}$ Wrongful life suits continue to be disallowed by the courts, while those same courts allow wrongful birth suits by the parents to collect for the expenses of raising the im-

Mr. Furrow is Visiting Professor of Law at the University of Michigan Lau'School in Ann Arbor, and Professor of Law' (on leave) at Washington College of Law, American Unitersity in Washington, D.C.

100 Lau: Medicine o Health Care paired child. ${ }^{3}$ The judicial struggle reveals the courts stalled in transition from a refusal to recognize any claims for damages by parents or children to a full recognition of claims by parents and children. I have explored in a previous article the connection berween such suits and the expansion of diag. nostic knowledge and medical technologies in the area of genetics. ${ }^{4}$ The proliferation of suits by parents who relied on medical advice to their detriment is understandable; what is not understandable is the courts' reluctance to acknowledge as valid the claims of the child. The courts find themselves forced into "an evaluation not only of law, but also of morals, medicine and society," 5 but seem unable to break free from self-imposed logical barriers and the "semantic quicksand" "which block insight into the issues. I propose to consider the arguments against the diminished life suits, as most recently raised in three cases decided within the last year in California and Pennsylvania, to sort out the real from the spurious issues, and to offer a more reasonable way of viewing such suits in light of the func tions of tort litigation. An important first step in clarifying the issues is to replace the term "wrongful life" in order to reduce the semantic overload of a phrase that tends to "confuse and confound." The phrase "diminished life" may help to liberate our thinking in this difficult and troubling area.

"Diminished life" suits are precipitated by a range of medical failures in assessing data and conveying information to potential parents. Medicine in the area of diagnosis of genetic defects is in transition from a stage of relative ignorance to an intermediate stage at which information as to a spectrum of disorders can be ascertained. The real problem concerns the treatment that is based on such information. Prevention of conception of a possibly defec- tive child or abortion remain the "treatment," and such prevention or termination does not fit neatly into the categories of treatment with which we are comfortable. Prenatal diagnosis and treatment can be viewed as a series of stages to illuminate this insight.

Stage 1, based on parent or family genetic histories or testing of the parents,

An important first step in clarifying the issues is to replace the term "wrongful life" in order to reduce the semantic overload of a phrase that tends to "confuse and confound." The phrase "diminished life" may help to liberate our thinking in this difficult and troubling area.

allows a genetic disorder to be anticipated by using Mendelian genetic predictions. Accurate information, when disclosed to the parents, allows them to make a choice whether or not to have a child. Stage 2 , the present state of the art in genetic diagnosis, ${ }^{9}$ involves the use of techniques for prenatal diagnosis of the fetus, including amniocentesis, visualization of the fetus through ultrasonography or a fetoscope, and sampling of fetal blood and serum to detect certain autosomal recessive disorders. This stage focuses on the fetus, and therefore "treat ment" moves from prevention to termination through abortion, if defects unacceptable to the parents are detected.

Stage 3, treatment of genetic disorders in utero, is the least developed. ${ }^{10}$ Termination of the pregnancy remains the only real option for most disorders diagnosed during pregnancy. An example of significant in utero treatments is methylmalonic aciduria, an autosomal recessive disorder responding to administrations of vitamin $\mathrm{B}_{12}$. "Medical knowledge in this area is in transition, and the legal system is 
caught on the horns of the dilemma created by current medical limitations. Advances in methods of gene manipulation may portend improved models for understanding human genetic diseases and correcting them. ${ }^{12}$ At present, however, prevention of conception and abortion of genetically impaired fetuses remain the two available "treatments" for genetic defects. Only in science fiction are corrective techniques fully developed. ${ }^{13}$

Three hypothetical cases involving an impaired newborn may illuminate the roots of the present controversy over the "diminished life" suit."

Case 1. While in a hospital's newborn nursery, a premature newborn shows symptoms of jaundice from liver malfunctioning. The bilirubin test results are incorrectly read, and the child is released without treatment of the infant's condition. The ultimate result is bilirubin toxicity, resulting in mental retardation of the infant.

Case 2. A woman is pregnant with a fetus suffering from rare methylmalonic aciduria. The condition is not detected by tests that were administered and, therefore, corrective vitamin therapy is not administered. When the child is born it is retarded.

Case 3. A pregnant woman undergoes tests to determine if her fetus is suffering from genetic disorders. Amniocentesis is conducted, but the testing laboratory negligently misreads the results, so that Down syndrome is not detected. Again the child is born retarded.

In all three cases, the result is a serious impairment of the newborn child. The negligence in all cases involves a similar failure to test properly for defects. Why should we allow both the parents and the child to sue in cases 1 and 2, but only the parents in case 3 ? The critical difference seems to lie in the nature of the treatment and its causal relationship to the harm. In Case 1 , sustained exposure to light will correct the condition and the child will be normal, and in case 2, vitamin therapy will solve the problem. In case 3 , however, no treatment in utero or after birth can correct the condition. Abortion is the only means the parents have for dealing with the psychic and monetary costs that an impaired infant will present. Notwithstanding that abortion is a morally and politically sensitive subject, is the difference between treatment and an informed choice as to termination great enough to justify recovery in cases 1 and 2 but not in 3 ? In all three cases, the children are comparably impaired, the parents subjected to comparable expenses and pain and suffering, and the negligence of the medical personnel equally culpable. The condition of the third child cannot be described as qualitatively different, nor is the negligence in case 3 less objectionable than in cases 1 or 2 . The primary difference is that in cases 1 and 2, the physician failed to diagnose and treat, thereby causing the impairment, whereas in case 3 the physician did not, by failing to treat, cause the Mongolism. By failing to diagnose, however, he denied the parents their option to "treat" by aborting the child. ${ }^{15}$ We need to take a hard look at the courts' justifications for distinguishing these situations, to test whether they withstand tests of logic, fairness, and consistency with tort principles.

\section{The Judicial Debate}

Three recent decisions, Speck $v$. Fine gold from Pennsylvania, ${ }^{16}$ and the California appellate and Supreme Court decisions in Turpin v. Sortini, ${ }^{17}$ present in sharp focus the continuing judicial struggle with the "diminished life" claims. The cases highlight the tensions which such claims present, and reveal judicial movement in two major jurisdictions toward full recognition of the claims of an impaired child. The California Court of Appeals for the Fifth District, in Turpin, rejected a claim by the infant plaintiff and explicitly rejected the holding and reasoning of its sister court which a year earlier had allowed such an action in Curlender v. Bio-Science Laboratories. ${ }^{18}$ The supreme court, faced with the lower court conflict in Turpin and Curlender, recently considered the "diminished life" claims raised in these cases. ${ }^{19}$ It allowed the infant plaintiff to bring a suit on her behalf, while simultaneously restricting damages available in the event of a finding of $\mathrm{li}$ ability. Turpin involved a plaintiff, Joy, born with a hereditary total deafness abnormality. The complaint alleged that the defendant physicians were negligent for failing to diagnose the defect in the plaintiff's older sister Hope and in advising the parents that Hope's hearing was within normal limits, when in fact a careful examination would have revealed that she was totally deaf. In reliance on the defendant's diagnosis of Hope, Joy was conceived. The complaint alleged that as a result of defendant's negligence, Joy was "deprived of the fundamental right of a child to be born as a whole, functional human being without total deafness, all to her general damages." 20

In Turpin, the California Su-
preme Court allowed the infant
plaintiff to sue on her own be-
half for the costs of special care,
training, and other special costs
that may arise. The court, how-
ever, denied recovery for general
damages, pain and suffering,
and emotional distress.

The Court of Appeals rejected the "diminished life" claim by the infant plaintiff, while acknowledging that a claim by the parents for special damages and extraordinary care was validly asserted. " The California Supreme Court, in a 4-2 opinion, allowed the infant plaintiff Joy to sue on her own behalf for the costs of special care, training, and other special costs that might arise. The court denied potential recovery, however, for general damages (those which cannot be specifically established by medical testimony or tangible proofs), pain and suffering, and emotional distress, in a curious opinion which allowed the cause of action while at the same time accepting many of the arguments made by other courts against the allowance of "diminished life" claims."2

Speck $v$. Finegold involved an infant suffering from neurofibromatosis. The father suffered from the disease, their previous two children inherited it, and the parents decided not to have more children. The father underwent a vasecromy and was told that he was ster. ile; nonetheless his wife subsequently became pregnant. She then sought an abortion, which another defendant 
failed to perform properly and she gave birth four months later to Francine, who had neurofibromatosis. The Pennsylvania Supreme Court held that the parents had a claim against the defendant physicians to recover expenses attributable to the birth and raising of the child, and for mental distress and physical inconvenience related to the birth. The court split evenly on the child's "diminished life" claim, however, and the lower court's denial of the cause of action therefore was affirmed.

The opinions in Turpin,, Turpin, and Speck raise three areas of dispute with regard to "diminished life" suits: (1) the problem of calculating damages; (2) the logical dilemma of allowing a party to sue when, absent the asserted negligence, the plaintiff would not exist; and (3) the possible consequences of allowing such claims for fear of opening a Pandora's box of parent-child litigation and government regulation.

\section{The Problem of Measuring Dam- ages: Too Narrow a View}

The fundamental difficulty, in the eyes of the Turpin, majority, is that of "measuring damages, that is, comparing the value of impaired life against no life." 23 The court quoted from the first case that considered and then rejected a child's "diminished life" claim, Gleitman u. Cosgrove:24

The normal measure of damages in tort actions is compensatory. Damages are measured by comparing the condition plaintiff would have been in, had the defendants not been negligent, with plaintiff's impaired condition as a result of the negligence. ${ }^{25}$

The court then quoted from the lower court opinion in Speck $v$. Finegold ${ }^{26}$ to reiterate the same thesis:

The remedy afforded an injured party in negligence is intended to place the injured party in the position he would have occupied but for the negligence of the defendant. Thus, a cause of action brought on behalf of an infant seeking recovery for a "wrongful life" on grounds she should not have been born demands a calcu- lation of damages between Hobson's choice of life in an impaired state and nonexistence. This the law is incapable of doing. ${ }^{27}$

The court's position is that (1) computation of tort damages requires a benchmark starting point against which to measure the harm suffered by the claimant, (2) the usual comparison point is the claimant's condition prior to the act of negligence, or the condition he would be in if no negligence occurred, (3) nonexistence does not provide a workable starting point, and therefore (4) the courts cannot compute damages. The position is that of logical impossibility, based on a process of deductive reasoning from socalled first principles of damage law. The Turpin court, again quoting from Gleitman, makes this clear:

By asserting that he should not have been born, the infant plaintiff makes it logically impossible for a court to measure his alleged damages because of the impossibility of making the comparison required by compensatory remedies. ${ }^{28}$

In Turpin 2 , the majority of the California Supreme Court was troubled, as was the lower court in Turpin , by the problem of comparing life to nonlife and assessing damages. Justice Kaus, writing for the majority, rejected general damages because of a perception that judges and juries would find it "simply impossible" to decide if any impaired life is better than no life at all. ${ }^{29}$ Thus, a notion of logical impossibility continues to haunt the discussion in the recent cases, even when, as in Turpin 2 , the court opens the door to the cause of action. The reasoning of Turpin, (and by implication of Gleitman and of the lower court opinion in Speck) does not withstand analysis. First, the argument from first principles of damage remedies is incorrect, taking far too narrow a view of the function of damages in tort law. Dam ages represent a crude means by which courts value an injury in dollar terms, requiring that a defendant pay a plaintiff "to make up for some loss that was not, originally, a money loss, but one that ordinarily may be measured in money." ${ }^{30}$ Special damages, including out-of-pocket expenses and medical expenses, can normally be quantified by reference to the before-and-after condition of the plaintiff. Such a before-and-after comparison is not inherently or logically required, however, and only reflects a convenient measure for comparison. Other categories of damages do not allow for such precision in calculation based on beforeand-after reference points. Nonpecuniary damages, such as pain and suffering, ${ }^{31}$ are not compensatory in the sense that they represent compensation for a loss measurable in money. "The real purpose in such cases," writes Dobbs, "is to establish and vindicate a right that is deemed important." "32 General damages, not tied to quantifiable proof, serve to vindicate the substantive right that the law seeks to protect, serving as "the ultimate expression of the plaintiff's right." "3 The rules surrounding damages are basically expressions of substantive policy, providing where possible convenient

Nothing in the axioms of damage remedies precludes evaluation of "diminished life" claims. Resolving the rights of the child by toying with damage remedies avoids the central issue of whether or not these suits fit squarely within traditional tort causes of action.

measures to express the valued right which was impaired in a given case. Nothing in the axioms of damage remedies preclude evaluation of "diminished life" claims, since the axioms are merely shorthand expressions for a complex range of policies and a normal set of cases. The deduction from axioms does not bar recovery; rather the importance of the right compels an altered reference point for measuring damages.

Even if the logical dilemma can be surmounted, the Turpin, court then argued that assessing general damages rationally "in any fair, non-speculative manner" would be "impossible" and "outside the realm of human competence." This concern was apparent in Turpin $_{1}$ in Speck, and in many other cases considering "diminished life" suits. On this reading, the trier of fact, 
whether judge or jury, is simply incapable of comparing life to nonlife for practical reasons.

Yet, this position is inconsistent with comparisons which juries make all the time in a variety of cases: in wrongful death cases, a previous condition of life, which may be impaired to a lesser or greater extent, is compared to nonexistence; in personal injury cases, an impaired state after an accident is compared to a normal, or in some cases, less impaired state before the accident. ${ }^{34}$ In all cases where pain and suffering are claimed, the trier of fact must assess such suffering against a benchmark of either no suffering or a lesser degree. The calculations are difficult, but not intractably so, or we would reject damage claims in a far greater number of cases than at present. The jury is often forced to make an empathetic leap, placing itself in the plaintiff's position in order to assess physical and psychological impairments of pain and suffering. ${ }^{35}$ Under our system of jurisprudence, as Alexander Capron points out, even when damages are difficult to assess, "subjective calculations about the 'value' of lives cut short, of pain and suffering, and of other intangibles, are left to juries and other legal factfinders." 36 The diminished life cases, like personal injury cases, involve comparisons of states of suffering. Judicial recycling of the sentiments expressed in earlier cases, without further comment and reflection on them, has not advanced the state of the debate. The plurality opinion in Speck, which advocated recognition of the "diminished life" cause of action, described the position taken by the majority of courts as "hyperscholastic" 37 ignoring the reality of the existence of the impaired plaintiff:

Those holding such views are apparently able to overlook what is plain to see: that - in cases such as this - a diseased plaintiff exists and, taking the allegations of the complaint as true, would not exist at all but for the negligence of the defendants. Existence in itself can hardly be characterized as an injury, but when existence is foreseeably and inextricably coupled with a disease, such an existence, depending upon the na- ture of the disease, may be intolerably burdensome. ${ }^{38}$

Even the California Supreme Court, in Turpin $_{2}$, by allowing only limited recovery for specifically provable damages, offered a halfway recovery which cannot be rationalized by normal tort principles and functions. The court in Turpin ${ }_{2}$ distinguished "diminished life" cases from all other tort cases, for purposes of assessing damages, without a convincing justification. Damages for pain and suffering, as one example, may buy comfort for a plaintiff, above and beyond special costs for medical care and extra training. In addition, the court fails to recognize or acknowledge that such elements of recovery as pain and suffering are also "an economic resource for the payment of attorneys' fees." 39 Since the American system does not generally require that the loser pay costs and attorneys' fees, and since the lawyer's contingency fee, if the plaintiff prevails, will consume one-fourth to onethird of the award, the additional reserve provided by pain and suffering awards is valuable. A more general criticism of Turpin 2 is that no coherent justification can be advanced to place "diminished life" suits in a special category of restricted recovery. As the dissent noted in Turpin ${ }_{2}$ :

$[N]$ o principle of law ... justifies so neatly circumseribing the nature of damages suffered as a result of defendant's negligence. ${ }^{40}$

The dilemma of the infant's claims in the diminished life suits continues to give the courts difficulty, as Turpin ${ }_{1}$, Turpin, and Speck reveal. Resolving the rights of the child by toying with damage remedies avoids the central issue of whether or not these suits fit squarely within traditional tort causes of action.

\section{The Problem of the Right: A Judi-} cial Life-Negating Stance?

The courts in Turpin, Turpin, and Speck assert a proposition that transcends either logical impossibility, as measured by tort principles, or practical impossibility, as measured by the limitations on triers of fact. Underlying the strong positions of some of the cases is a claim that life is always better than nonlife. This operates as a statement of substantive policy, an irrebutable presumption of the intrinsic value of life, no matter how impaired. In another "diminished life" case, the court wrote:

No man is perfect. Each of us suffers from some ailments or de. fects, whether major or minor, which make impossible participation in all the activities the world has to offer. But our lives are not thereby rendered less precious than those of others whose defects are less pervasive or less severe. ${ }^{41}$

The Turpin and Speck courts are reluctant to take a position which seems to state that a life is "wrongful," less valuable than nonexistence. If then any life, no matter how flawed, is al-

The Turpin and Speck courts are reluctant to take a position which seems to state that a life is "wrongful" and less valuable than nonexistence.

ways better than nonlife, a damage claim would indeed be pointless. Yet, we can imagine situations in which nonlife may be preferable: the burn victim with nerves exposed, the elderly patient linked to medical apparatus, even the young person, like Ken Harrison in Brian Clark's play, Whose Life is It Anyway?, who prefers nonexistence to impaired life. Courts have recognized that life might be intolerable, under certain circumstances. ${ }^{2}$ Thus, the right of a terminally ill adult to refuse further medical treatment, even though it may result in hastening his death, has been recognized. ${ }^{43}$ Legislatures have taken this one step further by permitting "living wills," giving legal protection to individual preferences concerning the cessation of medical treatment. ${ }^{44}$ The newborn nursery has come to present a new paradigm for the tension between impaired life and nonlife, as parents and medical staff struggle with nontreatment decisions. ${ }^{45}$ Little case law has emerged, but commentators have advocated legal protection for decisions against treatment when agreed upon by parents and physicians. ${ }^{46}$ Clearly, nonexistence is chosen over existence, in 
special circumstances, by parents, by courts, and by individuals.

Next, what is the "right" asserted in "diminished life" cases? Is the recognition of a cause of action by the impaired child equivalent to acknowledging a legal right on his part not to be born? One commentator, noting the conflict between the California courts in Curlender and Turpin, predicted that the California Supreme Court would not allow an individual to collect damages for having been born, no matter what his condition might be. He writes: "Although the law has grown to enormous complexity, as has our society, there simply can be no legal right not to be born. "4 7 If we accept that the life of an impaired child is wrongful, then it might be argued that "only his death can be rightful." 48 This concern pervades the cases: by authorizing an action by the child, the courts will be adopting a life-negating stance. They will be making, indirectly, a negative "social worth evaluation." 49 The courts are struggling to affirm eroding values, reflecting society's debate over abortion, and trying to avoid the appearance of making a judgment, as a representative of the State, of individual merit. They do not want to appear to decide against an individual life. ${ }^{50}$

The "right" at stake in the "diminished life" suit is not a right not to be born, since one logical corollary is that the child or its parents is not seeking its death. Rather, the right is to be part of a family unit in which fully informed decisions as to reproduction have been made. ${ }^{5}$ The wrong clearly illustrates this, since the breach of duty in these cases is the failure of the physician or laboratory to provide full, accurate information to the parents about their genetic legacy, leading to an incompletely informed decision. The child's right is illuminated by the remedies - compensation for pain and suffering, the child's special expenses beyond the age of majority, and the damage done to him by becoming part of a family in which his parents will labor under the burden of the extraordinary responsibilities of coping with severe impairment. The existential reality of the child, that he exists and suffers, is ack nowledged by allowance of his claim. Judge Kauffman, writing a separate opinion in the Speck case, makes this point:

Before us, unfortunately, is a liv. ing and breathing, but incurably diseased, deformed and suffering human being who never had a chance to be born healthy and who will be in need of extraordinary medical and other special care for the rest of her days. Any argument that this life of suffering is not the natural and probable consequence of appellees' misconduct is rank sophistry. ${ }^{52}$

An award of damages to a person born with defects entails a judgment only that the person's predicament imposes psychological and financial burdens on the child, the parents, and siblings, that ought in fairness to be borne by someone else, ${ }^{53}$ when that other person, whose expertise was relied upon by parents in making a reproductive decision, failed through his negligence to deliver correct information. The judicial difficulties stem in part from the semantic trap that a finding for a plaintiff is a judicial statement that his life is "wrongful." Only a recharacterization of the tort can free the courts to look more broadly at the rights involved. Whether we call the tort "genetic malpractice," 54 "diminished life," or just plain malpractice, it would be a first step away from an unnecessarily rigid position.

\section{Pandora's Box: Keeping the Lid On}

In recent cases such as Turpin and Speck, the judicial concern that recognition of this tort constitutes a lifenegating stance is accompanied by fears of opening up a Pandora's box of parent-child suits - "enormous new areas of claims, the true nature and extent of which cannot be predicted." "s The court in Curlender had indirectly created the problem; it suggested in dicta that, where parents made a conscious decision to proceed with a pregnancy, after they had been fully warned, it saw "no sound public policy which should protect those parents from being answerable for the pain, suffering, and misery which they have wrought upon their offspring." 56 This statement suggests a right on behalf of an impaired child to sue its parents when they failed to get proper medical advice or to control their life style, and injury to the infant occurs. This troubling possibility was promptly repudiated by the California legislature. ${ }^{57}$ However, such parent-child suits do not flow inevitably from allowance of "diminished life" suits, but must themselves be specifically allowed by the courts. Given the problems which parent-child suits might create, they could be barred either judicially or legislatively, or allowed only in exceptional cases when the parents acted with malice and intent to cause harm. ${ }^{58}$ Such cases would not involve the usual "diminished life" situation.

A second concern is that "diminished life" suits could be considered to assert a right to normalcy. This claim could justify state intervention in the form of a bureaucratic system of controls over reproduction to ensure an infant's health. ${ }^{59}$ Some commentators

Recognition of a child's right to sue, separate from the parent's right, does not connote a judicial acknowledgement that the child's life is "wrongful," in the sense that death should follow. The cause of action is simply recognition of a harm, linked to a medical failure, which deserves compensation.

urge a vigorous use of genetic knowl edge to screen out genetically unfit children, ${ }^{60}$ or at least to ensure through legal action that "fetuses destined to be born alive are not handicapped mentally and physically by the negligent acts or omissions of others." ${ }^{1}$ It is unlikely, however, that any impetus toward governmental controls over reproduction for the sake of infant health will derive from judicial recognition of diminished life claims. A shift in social attitudes is likely to precede such a change in regulation of the parent-child relationship. "Diminished life" suits do not require or compel such a value shift, since the nature of the claim is not normaicy, but rather compensation for the expenses and suffering of an impaired status.

Courts can keep the lid on this Pandora's box by carefully limiting " $\mathrm{di}$ - 
minished life" suits to block claims by the child against his parents. Legislatively imposed genetic screening is unlikely to be triggered by "diminished life" suits, but rather will result only if social values shift far more dramatically than present evidence suggests that they will.

\section{Functions of Tort Suits: Awarding, Deterring, Validating}

A tort suit may serve a variety of functions, including compensating the injured party, deterring future negligence by the defendant and by others in the same activity, and articulating and validating social norms. ${ }^{62}$ Will a "diminished life" suit by the child serve any of these functions, or add anything to the wrongful birth suit brought by his or her parents? I suggest that allowance of the child's suit will add a great deal to the possible benefcial effects of tort litigation in this area.

Compensation is a central function of tort suits. Such suits offer the plaintiff an institutional means of valuing the loss and compelling payment for that loss from the responsible agent. Wrongful birth suits, now allowed by most jurisdictions which have considered the question, entitle the parents of impaired children to sue for their medical expenses, special costs in rearing the child, and pain and suffering and emotional distress. ${ }^{63} \mathrm{~A}$ "diminished life" claim adds several additional elements of recovery. First, the pain and suffering of the child during its expected life span is a claim separate from that of its parents, ${ }^{64}$ and could amount to a substantial claim if the child's life expectancy were not cut short by the genetic defect. Second, the child might have special expenses, including costs of maintenance, after his age of majority. Since the parents' claims for compensation will presumably terminate at that age, a child's claim will allow the support obligation to be continued by the negligent party. As Judge Andreen argues in his dissenting opinion in Turpin : $_{1}$ :

[I] it is appropriate to award the parents special damages for the extra cost of living incurred because of a loss of hearing, why should not the child have a recov- ery measured by the same criteria for her life after she attains majority? ${ }^{65}$

The claim by the child therefore serves an important function by providing compensation for a range of expenses for which the parents are not entitled to recover ${ }^{66}$ The court in Turpin, has thus gone halfway toward this position by allowing special damages to the child, above and beyond claims by the parents.

The deterrent function of tort suits results from the coupling of compensation with payment by the party who negligently caused the harm. A compensation system for injuries need not make such a linkage; indeed, a tax-supported fund from which victims collect, modelled on the New Zealand system, might more effectively serve the compensation function. ${ }^{67}$ The deterrent effect on the negligent tortfeasor would be lost, however, and it is the coupling of the two functions which distinguishes most aspects of the American tort system. ${ }^{68}$ Damage awards to plaintiffs are a "signal" to defendants such as doctors, informing them how much to invest in order to avoid future accidents. ${ }^{69}$ Effective deterrence may not be achieved, because distortions in the system, such as the impact of medical malpractice insurance, dissipate the burden of a damage award, but in theory and to some extent in practice, some incentives to change can be expected. ${ }^{70}$

Whether the suit is against the physician or the testing laboratory, allowing the child's claim separate from his parents' is essential to deterring suboptimal medical behavior. Facts like those presented in Turpin make the point most strongly. In Turpin, the plaintiff Joy was born with a hereditary total deafness abnormality. It may be in this case that the child's condition will not require substantial cost in continuing medical care, so that the parents can recover only for their pain and suffering and other more limited special damages. The child's pain and suffering may, however, exceed by a substantial amount the parents' total potential recovery, over her lifetime, a possibility which the courts have failed to recognize. In this situation, the true costs of the injury to the fam- ily unit are significantly understated, and are finally borne in large part by the child and her family rather than by the negligent defendants. ${ }^{\text {" The defen- }}$ dant is not being forced to bear the full costs imposed by his negligent conduct, so that the deterrent effect of the damage award is reduced; therefore, too high a level of negligent conduct will result in the future. Underpricing the tort prevents the optimal level of care from being achieved.

The deterrent function may be more central to suits involving genetic malpractice than to malpractice suits in general, for two reasons. First, the field of genetic counseling is new; litigation focussed on standards of practice will help the field to coalesce around acceptable norms of practice. ${ }^{72}$ The pressure of litigation may spur practitioners to reduce the uncertainties by agreeing on norms of practice. Such a consensus will reduce the hazards of losing a lawsuit and the financial pressures of increased malpractice rates from proliferating litigation. Second, the source of the data which the physician or counselor must interpret and translate for the parents comes from prenatal diagnostic laboratories. Currently the laboratories performing prenatal diagnosis are underregulated, and operate under widely varying standards.$^{73}$ Control has come from the affiliation of these laboratories with university medical centers, where peer scrutiny and other constraints are present. Commercial laboratories are now proliferating, however, and their lack of affiliation and regulation may pose problems of unacceptable error rates. ${ }^{74} \mathrm{~A}$ concern that profit may dominate quality control has also been expressed. ${ }^{75}$ Tort suits involving such laboratories focus attention on their central role in diagnosing genetic disorders, possibly spurring state regulation. The financial burdens of losing a tort suit (or settling it) create incentives for the commercial laboratories to reduce their error rates. The economic effects of malpractice judgments on enterprises are likely to be greater than that on individual physicians, for reasons related to the expected economic rationality of the corporate enterprise in internalizing its costs of operations and performing cost-benefit 
calculations.

The articulation and validation of norms is a third function of tort suits. The nature of the norm involved in the "diminished life" cases has created the dilemma in which the courts now find themselves; if the norm is simply a right not to be born, we find it unpalatable. Likewise, a claim to be born normal seems to lead onto the slippery slope toward parent-child suits for acts which parents failed to take prior to conception or birth. Neither normalcy nor a right to nonexistence is the central value in these suits, however. The norm at issue can be viewed as primarily informational, deriving from accepted principles of personal autonorny, as reflected for example in informed consent doctrine. The parents, on this theory, when they seek genetic counseling or medical intervention to terminate a pregnancy where they know it is likely that they will have an impaired child, have a right to the communication by a physician of accurate information about the occurrence and risk of reoccurrence of genetic disorders within a family. ${ }^{76}$ The purpose of the information, or the preventive or termination procedure (sterilization, abortion), is to enable the parents to obtain and act upon accurate information in deciding whether to give birth to an impaired child. This norm clearly underpins the "wrongful birth" cases. What the "diminished life" action adds to this norm is the additional claim that the child has a right to be "equipped to meet life on some sort of an equal basis, " 77 by means of compensation for his suffering and necessary medical support. Alternatively, or perhaps additionally, the claim can be viewed as a family right, in which the child alone suffers from the "impaired parental capacity of the parents caused by physician dereliction." 18 In this analysis, the child's existence is diminished not only because of his inherent impairments and suffering, but also because of the incapacity induced in the parents by the child's impairments.

The right at stake in these cases needs to be better articulated, as part of the essential process of setting the boundaries of medical practice in an emerging field like genetic counseling. If the norms are seen as deriving prima- rily from a right to full information, when such information is sought by potential parents, then it can be viewed as reinforcing norms of individual autonomy and individual decision making in the area of reproduction. Such norms are neither novel nor unique, and suggest that "diminished life" suits do not present radically different problems for judicial resolution.

\section{Conclusion}

It is not surprising that courts are divided as to the merits of "diminished life" suits. Such suits represent the dilemma of medical abilities to produce information being more advanced than medical abilities to treat. The legal system has thus far failed to confront the issue in a manner consistent with tort doctrine, functions, and norms, but judicial movement toward recognition of these claims is becoming evident, as Turpin ${ }_{2}$ and Speck reveal. The damage problem can be resolved by focusing on the child's pain and suffering, and on a need for a fund, in some cases, to provide medical and other support if the child lives beyond the age of majority. Recognition of a child's right to sue, separate from the parent's right, does not connote a judicial acknowledgment that the child's life is "wrongful," in the sense that death should follow. The cause of action is simply recognition of a harm, linked to a medical failure, which deserves compensation. Nor must such suits lead inevitably to the specter of children suing parents, or of the state regulating all reproductive decisions for the sake of a standard of normalcy. Courts are professional line-drawers and spinners of distinctions, and in these cases as in others, hypothetical horrors need not follow inevitably from judicial allowance of such suits. Finally, courts need to take a careful look at the functions which litigation serves. While it is currently fashionable to describe our society as " $\mathrm{i}$ tigious," we must still be careful to sort out the values of a tort system, even as we expose the drawbacks. The impaired child, in some if not all cases, may need compensation beyond that which his parents can collect in a separate suit on their own behalf. Such re. covery may create pressure on a new medical specialty and the growing number of laboratories which analyze for genetic defects, to strive for the best performances possible. Such suits may further remind us of a value which may otherwise be lost in the debate that in a well-educated society, potential parents want the best information available about a decision as important as reproduction. If the time comes when treatment is available for most genetic impairments in utero or after birth, then the quandary of the "diminished life" suits will evaporate. Until such time, however, the courts must attempt to pierce the fuzzy thinking and confusions of wrongful life suits, and understand that they are not passing judgments on the merits of a life, but rather helping, through an award of damages, to enable an impaired plaintiff and his family to better endure his state of incapacity. The emerging judicial position, recognizing the "diminished life" cause of action, deserves to be recognized as consistent, coherent, and justifiable.

\section{References}

1. Thomas, L., Rx for lllich, NEw YORK RE. VIEW OF BOOKS 23(14): 3-4 (September 16 , 1976).

2. See generally Trotzig, M. The Defective

Child and the Actions for W'rongful Life and Wrongful Birth, FAMLL Y LAW QUARTERLY 14: 15-18 (1980).

3. For an extensive list of such decisions for "wrongful birth," see id at 15, n.6.

4. See Furrow, B., The Causes of "Wrongful Life" Suits: Ruminations on the Diffusion of Med cal Technologies, LAW, MEDICINE \& HEALTH CARE 10(1): 11 (February 1982).

5. Schroeder v. Perkel, 432 A.2d 834 (N.] 1981) at 841 .

6. The phrase is used by Judge Handler, concurring and dissenting in Schroeder v. Perkel. ld. at 845

7. $1 d$

8. Several diminished life suits have involved failures to convey correctly to parents the likelihood that their offspring would possess genetically transmitted impairments, based on the parents' history or defects apparent in another child in the family. See Moores v. Lucas, 405 So.2d 1022 (Fla. App. 1981) (Larsen's syndrome in morher); Schroeder v. Perkel, supra note 5 (first child suffered from cystic fibrosis; physicians treating first child failed to diagnose condition in time for parents to prevent or abort second pregnancy); Curlender v. Bio-Science Laboratories, 165 Cal. Rptr. 477 (Cal. App. 1980) (negligently conducted tests on parents for Tay-Sachs disease); Turpin v. Sortini, 174 Cal. Rptr. 128 (Cal. App. 1981 ) (improper diagnosis of older child as having a hereditary total deafness abnormality).

9. See generally, Omenn, Prenatal Diagnosis of Genetic Disotders, in Health Care: Regula. TION, ECONOMICS, ETHICS, PRACTICE (P. Abel- 
son, ed. 1978) at 151. Omenn groups the technologies chronologically, so that his first four stages are subsumed under my stage 2 which is oriented toward techniques involving the fetus. 10. Id at 157 .

11. Other examples include rare vitamin-re sponsive errors of metabolism, galactosemia and renogenital syndrome and hypothyroidism. Id.

12. Marx, Tracking Genes in Developing Mice SCIENCE 215(4528): 44,47 (1982). Methods of gene manipulation

may make possible the production of laboratory animat models that can be used to investigate human genetic dis eases for which such models are now lacking. Mice having Lesch-Lyhan syndrome, a severe neurological condition caused by a single defective gene, or the thalassemias, which are anemias caused by defective globin genes, are two examples.

13. See, e.g. F. HERBERT, The Eyes of HeisenBERG (Berkley, New York) (1966).

14. These cases were developed from a personal communication with Dr. H.M. Hildebrandt of Ann Arbor, Michigan (April 6, 1982)

15. This difference was pointed out to me by Professor Leonard Glantz, whose comments substantially improved this paper.

16. Speck v. Finegold, 439 A. $2 d 110$ (Pa. 1981)

17. Turpin v Sortini, 174 Cal Rptr 128 (Cal. App. 1981) [hereinafter referred to as Tur pin $_{1}$ ]; 182 Cal. Rptr. 337 (Cal. 1982) [hereinafter referred to as Turpin, ]

18. Curlender is "unsound under established principles of law and as a sortie into areas of public policy clearly within the competence of the Legislature." Turpin, , supra note 17, at 129.

19. Turpin, supra note 17.

20. Turpin, supra note 17 , at 129

21. Id at n. 2.

22. Turpin, supra note 17 , at $342-49$.

23. Turpin, supra note 17 , at 131

24. Gleitman v. Cosgrove, 227 A. $2 \mathrm{~d} 689$ (N.). 1967).

25. Turpin, supra note 17 , at 130 , groting

Gleit man v. Cosgrove, supra note 24, at 692.

26. Speck v. Finegold, 408 A. 2 d 496 ( $\mathrm{Pa}$. App. 1979).

27. Turpin, supra note 17 , at 130 , quoting Speck v. Finegold, supra note 26, at 508.

28. Turpin, supra note 17 , at 130 , quoting Gleitman v. Cosgrove, supra note 24, at 692 .

29. Turpin , supra note 17 , at 346.

30. D. DOBBS, HANDBOOK ON THE LAW OF REMEDIES \$3.1, at 135 (1973).

31. Id. at 136.

32. Id.

33. Id. $\$ 3.2$ at 142

34. For a detailed set of arguments in support of these propositions, see Capron, Tort Lia bility in Genetic Counseling, COLUMBIA LAw RE. V'IEW 79:618 (1979) at 648-49. Capton's article remains the best reasoned on the subject of w.rongful birth and life suits.

35. See, e.g., Steinhauser v. Hertz Corp., 421 F. $2 \mathrm{~d} 1169$ (2d Cir. 1970) where the claim was that an automobile accident had precipitated schizophrenia in the 14 year old plaintiff. Testimony in the case revealed that before the accident the plaintiff was "neither a 'pertectly normalchild' nor a schizophrenic, but a child with some degree of parhology which was activated into schizophrenia by an emotional trauma although it otherwise might not have blossomed." Id. at 1172 (emphasis in original) Judge Friendly, concluding that the issue precipitating the cause was for the jury to decide, stated:

It is no answer that exact prediction of Cynthia's future apart from the accident is difficult or even impossible. However raxing such a problem may be for men who have devoted their lives to psychiatry, it is one for which a jury is ideally suited.

Id. at 1174 .

36. Capron, supra note 34 , at 649.

37. Speck v. Finegold, supra note 16 , at 115 (Flaherty, ].)

38. Id.

39. Dobbs, supra note 30 , at 136

40. Turpin , supra note 17 , at 349 .

41. Berman v. Allen, 404 A.2d 8, 13 (N.J. 1979).

42. See, e.g., In re Quinlan, 355 A.2d 647, cert. denied, sub nom. Karger v. New Jersey, 429 U.S. 922 (1976)

43. See, e.g. Satz v. Perlmutter, 362 So. $2 d$ 160, 162 (Fla. App. 1978): "[T]he condition is terminal, the patient's situation wretched and the continuation of his life temporary and totally artificial."

44. See, e.g., California Narural Death Act, CAL. HeAlth \& SAFETY CODE $\$ 87186-95$ (West Supp. 1977); ARk. STAT. ANN. \$\$82-3801 et seq. See generally. Comment, The California Natural Death Act: An Empirical Study of Physictans' Prac. tices, STANFORD LAW REVIEW 31: 913 (1979), particularly cases cired at $913-14, n .3$ and 4 .

45. Shaw, Ethical lssues in Pediatric Surgery: A National Survey of Pediatricians and Pediatric SuTgeons, Pediatrics 60: 588 (1977).

46. Taub, S., Withholding Treatment from Defective Newborns, LAW, MEDICINE \& HEALTH CARE 10(1):4,9 (February 1982): "[A] decision against treatment which is agreed upon by parent $s$ and physicians should be legally una ssailable provided certain procedural safeguards are in effect."

47. Sanderson, Comment: Wrongful Life in Califomia, MALPRACTICE REPORTER 1: 19 (January 15,1982 ).

48. Friedman, Legal Implications of Amniocen tesis, UNIVERSITY OF PENNSYLVANIA L.AW RE VIEW 123(1): $92,154.55$ (1974)

49. M.H. Shapiro, R.G. SpeCe, Bioethics AND THE LAW (West, St. Paul) (1981) at 471.

50. Katz, Process Design for Selection of Hemo dialysis and Organ Transplant Recipients, BUF. FALO LAW REVIEW 22(2): 373, $402-03$ (1973) Note, Asexual Reproduction and Genetic Engineering: A Constitutional Assessment of the Technology of Cloning, SOUTHERN CALIFORNIA LAW REVIEW 47: 476, 538-39 (1974). See genetally, G. CALA. BRESI, P. BOBBITT, TRAGIC ChOICES (Norton, New York City) (1978) (general discussion of how we as a society try to avoid mechanisms which explicitly require us to make individual designs about life or death

51. This point is made in Schroeder v. Perkel, supra note 5 , by both the majority and concurring opinion. The majority wrote

A family is woven of the fibers of life; if one strand is damaged, the whole structure may suffer. The filaments of family life, although individ. wally spun, create a web of interconnected legal interests.

Id. at 839.

52. Speck v. Finegold, supra note 16 , at 118.

53. See L. Tribe, Channelling Technolod Throvgh Law' (Bracton, Chicago) (1973) at 275-76. Such a description of the right suggest that the impaired child should have a cause of action against their parents if they choose not to be fully informed. This is a logical position but one which raises serious questions of the slippery slope sort discussed in this article.

54. Comment. A Preference for Nonexistence Wrongful Life and a Proposed Tort of Genetic Mal ptactice, SOUTHERN CALIFORNIA LAW REVIEW 55(2): 477 (1982) thereinafter cited as Preference for Nonexistence]

55. Turpin, supra note 17 , at 132.

56. Curlender v. Bio-Science Laboratories, supra note 8 , at 488 .

57. In 1981, a statute was enacted prohibit ing parent-child litigation:

No cause of action arises against a parent of a child based upon the claim that the child should not have been conceived or if conce ived, should not have been allowed to have been born alive.

1981 Cal Stats., ch. 331(a) (to be codified in

CAL. Civ. CODE \$43.6)

58. Prefetence for Nonexistence, supta note 54 at $509-10$

59. Annas, G.]. . Righting the Wrong of

"Wrongful Life." Hastings CENTER REPORT

11(1): $8(1981)$

60. See, e.g.. Fletcher, Knouledge, Risk, and the Right to Reproduce: A Limiting Principle, in Geneticsand the LaW (A. Milunsky, $G$.

Annas, eds.) (2nd ed. 1980) at 131.

61. Shaw, The Potential Plaintiff Preconception and Prenazal Torts, in GeNeTICS AND THE LAW, supra note 60 , at $225,229$.

62. See generally, G. CALABRESI, THE COSTSOF ACCIDENTS (Yale University Press, New Haven. Conn.) (1970)

63. The norms may be those of the professional group which is indirectly the target of the litigation, see Schuchman, Ethics and Legal Ethics: The Propriety of the Canons as a Group Moral Code, GEORGE WASHINGTON LAW REVIEW 37: 244 (1968); or norms of the larger society which the court is articulating, see Wellington, Com mon Law Rules and Constitutional Double Standards. YALE LAW JOURNAL 83: 221, 248 (1978).

64. The parents" pain and suffering has been the only disputed issue in many of the cases which have allowed the wrongful birth cause of action. See Becker v. Schwartz, 386 N.E.2d 807 (N.Y. 1978).

65. Turpin, supra note 17, at 134

66. Damages may not be paid out in a lump sum in such cases but can rather be disbursed at regular intervals, in order to avoid the problem of overpayment if the child dies prematurely.

67. See, e.g. Kronick, Communiry Responsi. bility for Accident Victims. HastenGS CeNTER RE. PORT 9(5): 1 I (1979). See generally, CALABRESl, supra note 62 .

68. INSTITUTE OFMEDICINE, BEYOND MALPRACTICE: COMPENSATION FOR MEDICAL IN. JURIES (1978) at 68 .

69. Schwartz, Kowesar, Doctors, Damages and Deterrence: An Economic Vieu of Medical Malpractice (Rand Corp. Report, June 1978)

Continued on page 114 
safely performed on an outpatient basis. The Act also directs the Secretary to certify as ambulatory surgical centers those facilities which provide the surgical procedures on an outpatient basis. The proposed rules on ambulatory surgical centers, issued in March 1982, would allow reimbursement to physicians for services provided in connection with each procedure of 100 percent of the reasonable charges (rather than the usual 80 percent reimbursement of physician services); additionally, the ambulatory surgical centers would receive reimbursement of the cost of providing service at a standard rate determined by HCFA. ${ }^{36}$

Ambulatory surgical centers were initially developed to avoid the high costs associated with minor surgery performed in hospitals. The goal of the 1980 Medicare Amendments - that services covered by the Medicare program be provided economically - may provide a basis for extending cost reimbursement to independent emergicenters in the future.

\section{Conclusion}

The development and operation of emergicenters may increase competition in the health care sector. As demonstrated above, however, there is a need for uniform standards applicable to emergicenters in such areas as promotion, facility capacity, equipment and staffing, as well as integration of the emergicenter with the local emer-. gency medical system. Developing standards in these areas may be advantageous to independent emergicenters to the extent that they allow more complete reimbursement by third party payors. Moreover, both hospitalsponsored and independent emergicenters should at least be subject to certain common regulatory requirements, thereby providing a more equitable basis for competition between the two basic models. However, in the process of developing standards, governmental agencies and professional organizations must be cognizant of the varied structures that currently exist. In doing so, the substantial primary care functions of emergicenters cannot be overlooked; careful consideration of this aspect of emergicenters will result in a reasonable degree of struc- tural diversity. In this way, the competitive element which emergicenters can bring to the health care industry can be effectively balanced with the need for reasonable protection of the public.

\section{References}

1. Rhode Island Deparment of Health, Rules and Regulations for the Licensing of Freestanding Emergency Care Facilities, R2317-FECF $\$ 1.1$ (December 30, 1981) [hereinafter cited as Rhode Island Rules and Regulations] 2. Id. at $\$ 1.2$.

3. Preamble and Principles of the National Association of Freestanding Emergency Centers (formerly known as the National Association of Centers for Urgent Treatment).

4. N.Y. Pub. HeALTH LAW \$2801(1)

(McKinney 1981)

5. MASS. Gen. LAws ANn, ch. $111, \$ 52$ (Michie/Law Coop 1982) ( $\$ 51$ requires licensure of clinics; $\$ 52$ defines what clinic is and is not).

6. Rhode Island Rules and Regulations, supra note 1 , at $\$ 2.2$.

7. Rhode Island Department of Health, Rules and Regulations for the Licensing of Freestanding Emergency Care Facilities, R23. 17.FECF (October 28, 1981)

8. For example, the Maryland Prince George's County Medical Soxiety recently adopted a resolution which would require regu lation of emergicenters if they use such terms as "emergency," "urgent," or other words which connote im mediate care capability for sudden or unexpected conditions that might potentially require life-saving measures. In addition, such facilit ies would be required to fulfill a de. fined role in the local emergency medical system.

9. 42 U.S.C. $\$ \$ 300 \mathrm{k}$ et seq. (1976 and Supp III 1979)

10. 45 Fed. Reg. 69,475 (1980) (to be codified at 42 C.F.R. $\$ 123.401$ ).

11 Id.

12. Special Report: Survey of State CON Lau',

HeAlth PlanNing Law Reporter 5(2\&3):1-7 (1982).

13. Burns, L., Ferber, M., Freestanding Emer. gency Care Centers Create Public Policy Issues, HoSPITALS 55(10): 75 (May 16, 1981).

14. National Association of Freestanding

Emergency Centers, Emergence (January 1982) at 3 .

15. 42 U.S.C. $\$ 1395 \mathrm{et} \mathrm{sed}$

16. 42 U.S.C. $\$ 1395$ (d)

17. 42 U.S.C. $81395(\mathrm{k})$.

18. 42 U.S.C. $\$ 1395(\mathrm{x})(\mathrm{u})$

19. 42 U.S.C. $\$ 1395(\mathrm{f})(\mathrm{b})$

20. 42 U.S.C. $\$ 1395$ (l)(a)

21. Wilmington Gen. Hosp. v. Manlove, 174

A. 2d 135 (Del. 1961).

22. Garcia v. Memorial Hospital, 557 S.W.2d 859 (Tx. Civ. App. 1977).

23. Hunt v. Palm Springs Gen. Hosp., Inc. 352 So. 2 d 582 (Fla. Dist. Ct. App. 1977).

24. Massachusetts Chapter of American College of Physicians, Position Paper on Free Standing Care Facilities, at 2.

25. Methodist Hosp. v. Ball, 362 S.W.2d 475 (Tenn. Cr. App. 1961).

26. New Biloxi Hosp., Inc. v. Frazier, 146 So.2d 882 (Miss. 1962).
27. Nance v. James Archer Smith Hosp., Inc., 329 So.2d 377 (Fla. Dist. Ct. App. 1976). 28. Rhode Island Rules and Regulations, supra note 1 , at $\$ 2.2$.

29. Id. at $\$ 7.0$

30. Id at $\$ 9.0$.

31. Id. at $\$ 10.0$.

32. Id. at $\$ 11.0$.

33. Id. at $\$ 16.0$

34. Id at $\$ 21.0$

35. Id. at $\$ 19.0$

36. 47 Fed. Reg. 12,574 (1982), corrected at 47 Fed. Reg. 13,174 (1982).

Furrow - references

continued from page 107

70. Roemer, Controlling and Promoting Quality in Medical Cate, LAW AND CONTEMPORARY Problems 35: 284, 297 (1970). For doubts as to the efficacy of such "signalling," see Brook. Brutoco, Williams, The Relationship Between Medica! Malpractice and Quality of Care. DUKE LAW JOURNAL 1975: 1197.

71. See Capron, The Continuing Wrong of "Wrongful Life," in GenETiCs AND THE LAW, supra note 60 , at 81 .

72. See Capron, supra note 34, at 625. See also Comment, Father and Mother Know Best: Defin ing the Liability of Physicians for Inadequate Ge netic Counseling, YALE LAW JOURNAL 87: 1488 (1978).

73. Milunsky, A., Prenatal Genetic Diagnosis and the Lau', in GENETICS AND THE LAW, supra note 60

74. See Golbus, et al. Prenatal Genetic Diag. nosis in 3000 Amniocenteses, NEW ENGLAND JOURNAL OF MEDICINE 300: 157 (1979).

75. Editorial, Prenatal Diagnosis of Doun's Syndrome, JOURNAL OF THE AMERICAN MEDICAL AsSOCIATION 242(21): 2326 (1979).

76. Healy, The Legal Obligations of Genetic Counselors, in GENETICS AND THE LAW, supta note 60 , at 74 .

77. Andreen, J. dissenting, Turpin, supra note 17 , at 135 .

78. This claim is most fully articulated by judge Handler in his opinion in Schroeder $v$. Perkel, supra note 5 , at 844

\section{Notice of ASLM Annual Meeting}

On Monday, July 19, 1982, at 5:30 p.m., the annual business meeting of the American Society of Law \& Medicine will be held at the Hyatt Regency Hotel in Cambridge, Massachusetts. The primary business of the meeting will be the election of members of the Board of Directors. All members of the Society are invited to attend. 